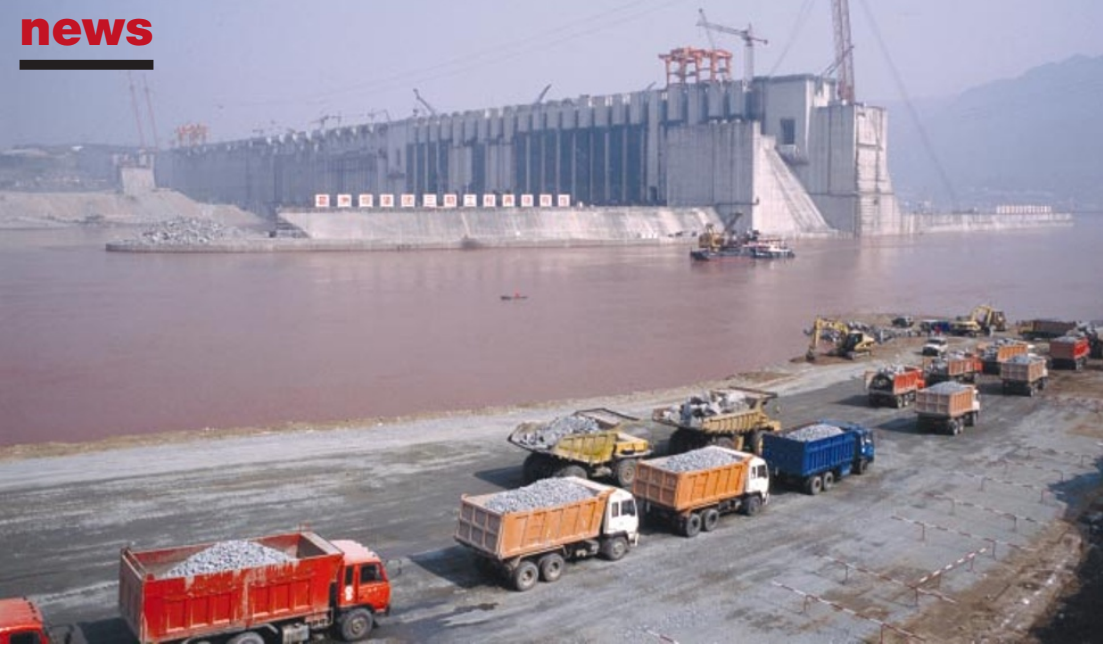

Big issue: projects such as the Three Gorges Dam on China's Yangtze River continue to make waves.

\title{
Conflicts undermine global forum's push for safe water
}

\section{David Cyranoski, Kyoto}

The organizers of last week's 3rd World Water Forum in Japan are saying that it succeeded in translating a vision for solving the global problems of water supply into action. But, upstaged by the war in Iraq and facing trenchant criticism from environmental groups, the forum struggled to win the recognition that its architects sought.

Some 24,000 people from 182 countries attended the event, held on 16-23 March in Osaka, Kyoto and nearby Shiga. By its close, 422 'water actions' — concrete measures by which different nations demonstrated their commitment to solving water problems had been submitted.

But critics said that most of these actions - as well as agreement on a six-page statement signed by ministerial delegates to the meeting from all countries - were arranged in advance. This left many participants asking whether the mammoth event had actually furthered the effort to secure safe water supplies.

Host nation Japan set the tone for the meeting by promising to spend $¥ 16$ billion (US\$133 million) this year to bring clean drinking water to people in poor countries, and to train 1,000 water-supply specialists over the next five years. It was one of several initiatives announced in pursuit of the United Nations' goal of halving the number of people without access to safe drinking water by 2015 (see Nature 422, 251-256;2003).

But the outbreak of war in Iraq took its toll on the meeting, with leading figures including Japanese foreign minister Yoriko Kawaguchi pulling out of the event. Reporters from across the world complained that their stories on the meeting were not finding space in news pages dominated by war coverage.

Speakers at the forum sought to align its goals with the international debate over the war. For example, former Japanese prime minister Ryutaro Hashimoto, who chaired the forum's steering committee, pledged to send experts to supply water to those displaced by the war.

Environmental groups, meanwhile, attacked the forum's ministerial statement for skirting controversial issues. Agnes van Ardenne, minister for development cooperation in the Netherlands, criticized the document for its silence on problems related to climate change and the private ownership of water, and questioned the need for future water forums.

Hydrologists and environmentalists at the meeting clashed over the value of large dam projects. Mahmoud Abu-Zeid, president of the World Water Council and the forum's co-organizer, called for a "large increase in the number of dams". But environmentalists attacked the ministerial statement for failing to address problems related to dam construction. "This is a very weak document," said Ger Bergkamp, coordinator of the World Conservation Union's water and nature initiative. Abu-Zeid pointed out that the forum couldn't be expected to solve such problems overnight. "We did not promise a treaty," he said.

Organizers said that the forum had exceeded expectations in its main function of building links between scientists, officials and activists engaged in water issues, noting that more than 100 new commitments to collaborate had emerged.

In a statement summing up the forum's achievements, World Water Council vicepresident William Cosgrove said that, despite the forum's conflicts, such commitments reflect attention to its key agreements "that community-level public participation is fundamental to achieving the goals of the forum", and "that the common basic requirement for water is an opportunity for cooperation and peace".

\section{Mystery virus slow to yield its identity as patient numbers rise}

\section{Helen Pearson, New York}

Health officials were intensifying their efforts this week to control an international outbreak of mystery pneumonia.

Officials at the World Health

Organization (WHO) are reporting a continuing rise in their tally of patients who have contracted the condition dubbed severe acute respiratory syndrome (SARS). As of 24 March, 456 cases and 17 deaths had been reported in 13 countries.

But doctors have partially succeeded in restricting the spread of SARS by isolating patients and using measures such as facemasks to block exposure to coughed-up droplets bearing the pathogen.

A worldwide group of at least 11 collaborating laboratories is also making headway in identifying the microorganism behind the disease, and developing a simple diagnostic test.

On 24 March, researchers at the US Centers for Disease Control and Prevention (CDC) in Atlanta, Georgia, reported that the SARS pathogen might be a new member of the coronavirus family, which includes viruses that cause some common colds and respiratory infections. Particles found in the tissues of some SARS patients had a similar structure and genetic sequence to known coronaviruses.

This followed suggestions last week that the pathogen responsible might be a previously unknown member of the Paramyxoviridae family, which includes the agents that cause measles and mumps.

But those involved in the investigation warn that these candidate viruses may simply be coincidental infections. Wolfgang Preiser at the Institute for Medical Virology in Frankfurt, Germany, says that it would be "premature to claim victory" in identifying the virus.

Preiser's laboratory, among others, is now attempting to grow the pathogen and match its genetic sequence with known specimens. But to prove beyond doubt that a candidate virus is causing SARS, additional 'gold-standard' tests will be needed, says virologist Albert Osterhaus of Erasmus University in Rotterdam, the Netherlands.

One such test is the enzyme-linked immunosorbent assay (ELISA), which can detect antibodies produced by the patient's immune system to fight a particular virus.

The CDC announced that it has already had some success with similar techniques and that several recovering patients seem to have antibodies against the coronavirus that they have isolated. 